\title{
Preliminary sensory evaluation of salty crackers with grape pomace flour
}

\author{
Avaliação sensorial preliminar de bolachas salgadas de farinha de bagaço de uva
}

\author{
M. Lídia Palma 1,2*, M. Cristiana Nunes ${ }^{1,2,3}$, Rita Gameiro ${ }^{2}$, Marta Rodrigues ${ }^{2}$, Sarah Gothe ${ }^{2}$, \\ Nelson Tavares ${ }^{1,2}$, Cíntia Pego ${ }^{1}$, Marisa Nicolai ${ }^{1,2}$, Paula Pereira ${ }^{1,2,4}$
}

${ }^{1}$ Center for Research in Biosciences \& Health Technologies (CBIOS), Universidade Lusófona de Humanidades e Tecnologias, 1749-024 Lisboa, Portugal; ${ }^{2}$ Universidade Lusófona de Humanidades e Tecnologias, 1749-024 Lisboa, Portugal ${ }^{3}$ LEAF-Linking Landscape, Environment, Agriculture and Food, Instituto Superior de Agronomia, Universidade de Lisboa. Tapada da Ajuda, 1349-017 Lisboa, Portugal; ${ }^{4}$ Center for Natural Resources and Environment (CERENA), Instituto Superior Técnico (IST), Universidade de Lisboa, Av. Rovisco Pais, 1049-001 Lisboa, Portugal

* Corresponding author: lidia.palma@ulusofona.pt

\begin{abstract}
Grape pomace, a by-product of winemaking, contains numerous chemical compounds with high nutritional value and potential benefits for human health, which enable its use for product enrichment in different industries from cosmetics to food. The aim of this study was to incorporate the grape pomace flour of the Touriga Nacional and Arinto grapes varietals from the Alentejo region of Portugal in a recipe for salty crackers, which were submitted to sensory evaluation by applying a hedonic test to 53 individuals. The results of the evaluation show a clear tendency of preference for the crackers with $10 \%$ of grape pomace flour, both in the Touriga Nacional and Arinto samples, which presented the highest result averages.
\end{abstract}

Keywords: grape pomace, salty crackers, sensory evaluation, Touriga Nacional, Arinto

\section{Resumo}

O bagaço de uva é o subproduto da vinificação que apresenta na sua constituição diversos compostos químicos com elevado valor nutritivo e potenciais benefícios para a saúde humana, o que viabiliza a sua utilização em diferentes indústrias desde a cosmética à alimentar, através do enriquecimento dos produtos. Este estudo teve assim como objetivo a incorporação de farinhas de bagaço da uva, resultantes da vinificação, das castas Touriga Nacional e Arinto, provenientes da região portuguesa do Alentejo, numa receita de bolachas salgadas, as quais foram submetidas à avaliação sensorial aplicando um teste hedónico a 53 indivíduos. Os resultados da avaliação sensorial revelam uma clara tendência de preferência pelas bolachas com incorporação de $10 \%$ de farinha de bagaço, tanto na amostra contendo Touriga Nacional como na amostra contendo Arinto, na medida em que foram as que apresentaram os parâmetros mais elevados.

Palavras-chave: bagaço de uva, bolachas salgadas, avaliação sensorial, Touriga Nacional, Arinto 


\section{Introduction}

In Portugal the wine industry is one of the main industries, not only in terms of production (6.1 million hectolitres of wine in 2018) but also in terms of trade balance $(8,041,480 €$ of exports), making Portugal the eleventh largest wine producer in the world (1).

However, the industrial production of wine generates a large volume of waste which, according to the International Wine Organization (2), corresponds to $25 \%$ of the weight of the grape. Thus, the annual wine production in Portugal creates around 200 kilotons/ year of winemaking residue, which is called grape pomace (3). Regulation (EC) 1493/1999 defines the grape pomace as the residue resulting from the pressing of fresh grapes, whether fermented or not during the winemaking process, constituted of stalks, stems, films, and grains. Depending on the grape pomace variety and the method used in winemaking, a red/fermented grape pomace or a sweet/fresh grape pomace can be obtained. In the production of white wines, the resulting sweet/ fresh grape pomace does not ferment along with the must and thus the wine has low alcohol content and high sugar content. Conversely, red/fermented grape pomace ferments together with the must to produce a wine with higher alcohol and lower sugar content (3). After winemaking, the waste produced can be used as fertilizer, as a raw material for the production of spirits and of tartaric acid, or disposed of in landfills, the latter being the least sustainable and with equally negative environmental consequences (4-6).

Given the growing interest in environmental preservation and in view of the economic value generated by this industry, the sustainable use of these wastes is imperative. Based on several studies, which highlight various components of great relevance from a nutritional point of view, grape pomace may, from this perspective, be used for human consumption. In this sense, after drying and grinding, the resulting by-products may give rise to a grape pomace flour rich in fibre, proteins, polyphenols, and antioxidant compounds (7-9).

Therefore, in this study this residue is proposed to be used in a sustainable, economical, environmentally, and socially advantageous manner through the incorporation of grape pomace flour into food for human consumption, namely salty crackers. In this way, conventional wheat flour is replaced by grape pomace flour, at percentages of $5 \%$ and $10 \%(\mathrm{w} / \mathrm{w})$, to nutritionally enrich the food. The resulting different crackers were then subjected to sensory evaluation with untrained tasters (10).

\section{Introdução}

Em Portugal a indústria vitivinícola é das principais indústrias, não só em termos produtivos $(6,1$ milhões de hectolitros de vinho em 2018), como em termos de balanço comercial (8.041.480 € em exportações), dados que fazem de Portugal o décimo primeiro produtor mundial de vinho (1).

A produção industrial de vinho gera contudo, um grande volume de resíduos que, segundo a Organização Internacional de Vinho (2), correspondem a $25 \%$ do peso da uva. Deste modo, a produção anual de vinho em Portugal origina, cerca de 200kilotoneladas/ano de resíduo da vinificação, o qual se designa por bagaço de uva (3). No Regulamento (CE) 1493/1999 estabelecese como bagaço, o resíduo resultante da prensagem das uvas frescas, fermentado ou não, durante o processo de produção de vinho, constituído por engaços, pedúnculos, películas e grainhas. Dependendo da casta e do método utilizado na vinificação, pode obter-se um bagaço tinto/fermentado ou um bagaço doce/fresco. Por um lado, na produção de vinhos brancos o bagaço resultante doce/fresco, não fermenta juntamente com o mosto e por isso o bagaço apresenta um baixo teor de álcool e elevado teor de açúcar. Por outro lado, o bagaço tinto/fermentado, fermenta em conjunto com o mosto dando origem a um bagaço com um teor de álcool mais elevado e menor teor de açúcar (3). Após a vinificação, os resíduos produzidos podem ser utilizados como fertilizantes, matéria-prima na produção de aguardentes e produção de ácido tartárico ou serem descartados em aterros, este último exemplo é não só menos sustentável e com consequências ambientais igualmente negativas (4-6).

Dado o crescente interesse na preservação ambiental e tendo também em vista o valor económico gerado por esta indústria, é imperativo o uso sustentável destes resíduos. Tendo por base diversos estudos, onde se realçam vários componentes de grande relevância do pondo de vista nutricional, o bagaço pode, nesta perspetiva, vir a ser utilizado na alimentação humana. Neste sentido, após secagem e moagem, a farinha de bagaço de uva resultantes dá origem a uma, rica em fibras, proteínas, polifenóis e compostos antioxidantes (7-9).

Assim, na sequência de diversas pesquisas que foram levadas a cabo, é proposto neste estudo a utilização deste resíduo de forma sustentável, económica, ambiental e socialmente vantajosa através da incorporação da farinha de bagaço de uva num alimento para consumo humano, nomeadamente bolachas salgadas. Desta forma, substitui-se a farinha de trigo convencional pela 
With the aim to assess the acceptability of the salty crackers, a preliminary sensory evaluation was used, as there are important advantages in the use of these tests with regard to the perception of the most relevant quality attributes for consumer acceptability. These tests are therefore universally used in order to determine the global preferences of consumers (11).

\section{Material and Methods}

\section{Biological samples}

Grape pomace samples of the Arinto and Touriga Nacional varieties were supplied by Adega Cooperativa Carmim, in Reguengos de Monsaraz, Alentejo, Portugal, corresponding to a white and red grape, respectively.

\section{Cracker preparation}

The formulation used in this study was produced according to a previously developed recipe (12). This recipe was used to prepare salty crackers without grape pomace flour, which were used as a control in this study, and was also used to produce the four other salty crackers containing grape pomace flour. All ingredients used are shown in Table 1.

Four different formulations were prepared with incorporation of grape pomace: cracker with 5\% incorporation of Arinto variety flour (Arinto 5\%); cracker with $10 \%$ incorporation of Arinto variety flour (Arinto 10\%); cracker with 5\% incorporation of Touriga Nacional variety flour (Touriga Nacional 5\%); and cracker with $10 \%$ incorporation of Touriga Nacional variety flour (Touriga Nacional 10\%) (Table 1).

Ingredients used included T55 Extra fine wheat flour (Nacional), refined white sugar (Sidul), fine table salt (Continente), sunflower oil (Fula), sodium bicarbonate (Royal), distilled water, and grape pomace flour.

To begin, all ingredients were added and mixed in a food processor (Bimby, Vorwerk), at position 4, for 2 min, to form a homogeneous dough. The dough was subsequently flattened in a manual rolling mill (Atlas, Marcato) at positions 2, 4, and 6. This step was repeated three times for each position. Then the dough was cut into a rectangular shape $(2.5 \mathrm{~cm} \times 2 \mathrm{~cm})$ and allow to rest for $10 \mathrm{~min}$, followed by baking in an electric oven (Arianna) at $160^{\circ} \mathrm{C}$ for $15 \mathrm{~min}$. Finally, the crackers were dried at $60^{\circ} \mathrm{C}$ for $30 \mathrm{~min}$. The procedure used is described in Figure 1. farinha de bagaço de uva, numa percentagem de $5 \%$ e $10 \%(\mathrm{~m} / \mathrm{m})$, de modo a enriquecer nutricionalmente o alimento. As diferentes bolachas salgadas resultantes, foram de seguida submetidas a uma avaliação sensorial preliminar com participantes provadores não treinados (10).

Com vista a avaliar a aceitabilidade dos alimentos confecionados, recorreu-se a uma avaliação sensorial, visto existirem importantes vantagens na utilização destes testes no que concerne à perceção de atributos de qualidade mais relevantes para a posterior aceitação por parte do consumidor. Estes testes são por isso universalmente usados de modo a determinar as preferências globais dos consumidores (11).

\section{Materiais e Métodos}

\section{Amostras biológicas}

As amostras de bagaço de uva das variedades de Arinto e Touriga Nacional foram fornecidas pela Adega Cooperativa Carmim, em Reguengos de Monsaraz, Alentejo, correspondendo a uma casta branca e uma tinta, respetivamente.

\section{Preparação das bolachas}

A formulação utilizada foi produzida de acordo com uma receita previamente desenvolvida (12). A receita original, sem farinha de bagaço de uva, foi usada como controlo, e para produzir as formulações contendo farinha de bagaço de uva. Todos os ingredientes constam na Tabela 1. Foram preparadas quatro formulações, com diferentes incorporações de farinha de bagaço da uva: bolacha com $5 \%$ de incorporação de farinha da casta Arinto (Arinto5\%); bolacha com 10\% de incorporação de farinha da casta Arinto (Arinto10\%); bolacha com $5 \%$ de incorporação de farinha de bagaço da casta de Touriga Nacional (Touriga 5\%); e bolacha com 10\% de incorporação de farinha de bagaço da casta de Touriga Nacional (Touriga 10\%) (Tabela 1).

Os ingredientes utilizados incluíram: farinha de trigo T55 extrafina (Nacional), açúcar branco refinado (Sidul), sal fino de mesa (Continente), óleo de girassol (Fula), bicarbonato de sódio, (Royal), água destilada e farinha de bagaço de uva.

Inicialmente todos os ingredientes foram adicionados e misturados num processador de alimentos (Bimby, Vorwerk), na posição 4, durante $2 \mathrm{~min}$, para a formação de uma massa homogénea. Esta foi posteriormente moldada na laminadora manual (Atlas, Marcato) nas posições 2,4 e 6 . Repetiu-se esta etapa três vezes para cada posição. De seguida, a massa foi cortada em for- 
Table 1 - Formulation of salty crackers ingredients

Tabela 1 - Ingredientes da formulação das bolachas salgadas

\begin{tabular}{|c|c|c|c|}
\hline $\begin{array}{l}\text { Ingredients / } \\
\text { Ingredientes }\end{array}$ & $\begin{array}{l}\text { Control / } \\
\text { Controlo }\end{array}$ & $\begin{array}{c}\mathbf{5 \%} \\
\text { Incorporation / } \\
\text { Incorporação } \\
\end{array}$ & $\begin{array}{c}10 \% \\
\text { Incorporation / } \\
\text { Incorporação } \\
\end{array}$ \\
\hline & \multicolumn{3}{|c|}{ Quantity / Quantidade (g) } \\
\hline $\begin{array}{l}\text { Wheat flour } \\
\text { Farinha de Trigo }\end{array}$ & $91.00 \pm 0.01$ & $83.50 \pm 0.01$ & $76.00 \pm 0.01$ \\
\hline $\begin{array}{l}\text { White sugar } \\
\text { Açúcar branco }\end{array}$ & $1.50 \pm 0.01$ & $1.50 \pm 0.01$ & $1.50 \pm 0.01$ \\
\hline $\begin{array}{l}\text { Fine salt } \\
\text { Sal fino }\end{array}$ & $1.50 \pm 0.01$ & $1.50 \pm 0.01$ & $1.50 \pm 0.01$ \\
\hline $\begin{array}{l}\text { Baking poder } \\
\text { Fermento químico }\end{array}$ & $2.25 \pm 0.01$ & $2.25 \pm 0.01$ & $2.25 \pm 0.01$ \\
\hline $\begin{array}{l}\text { Sunflower oil } \\
\text { Óleo de girassol }\end{array}$ & $11.25 \pm 0.01$ & $11.25 \pm 0.01$ & $11.25 \pm 0.01$ \\
\hline $\begin{array}{l}\text { Destilled Water } \\
\text { Água destilada }\end{array}$ & $42.50 \pm 0.01$ & $42.50 \pm 0.01$ & $42.50 \pm 0.01$ \\
\hline $\begin{array}{l}\text { Grape pomace flour } \\
\text { Farinha de bagaço de uva }\end{array}$ & - & $7.50 \pm 0.01$ & $15.00 \pm 0.01$ \\
\hline
\end{tabular}

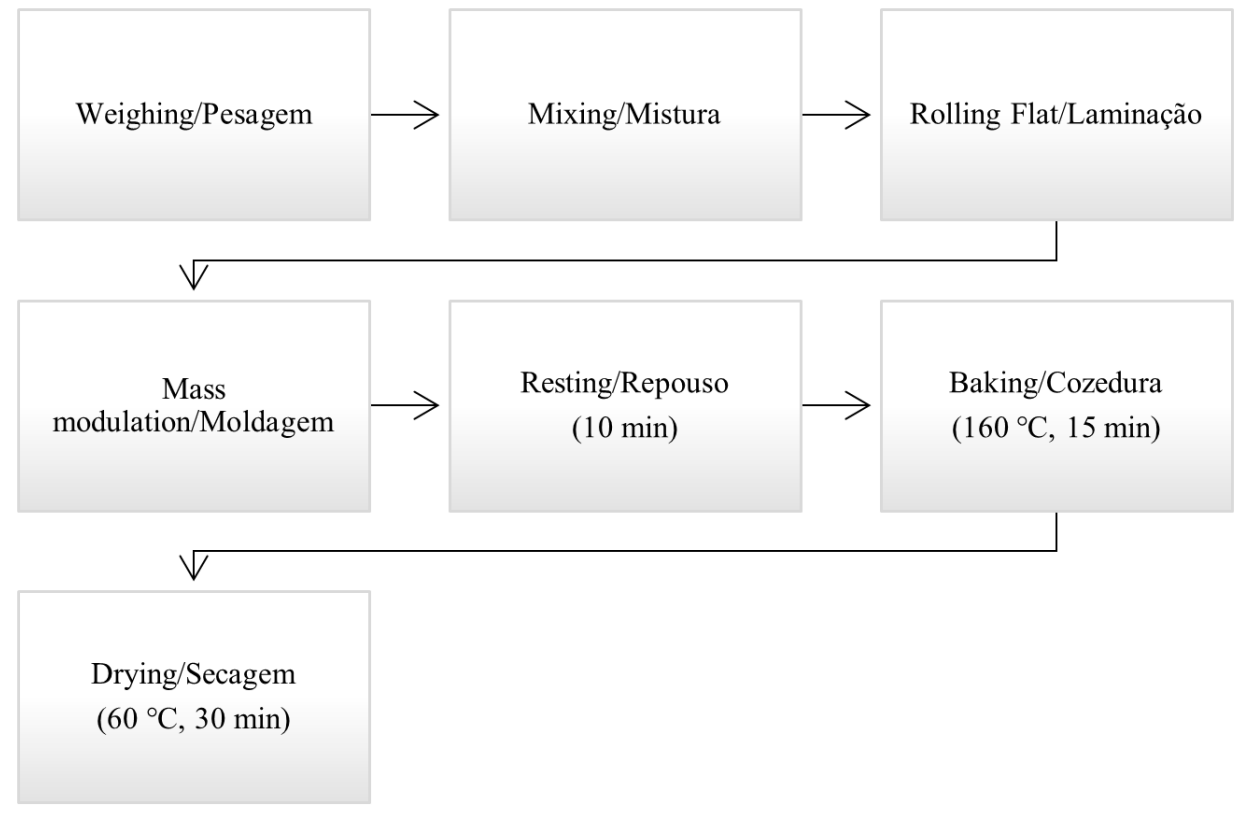

Figure 1 Preparation of salty crackers with incorporation of grape pomace flour Figura 1 - Preparação de bolachas salgadas com incorporação de farinha de bagaço 
Table 2 - Hedonic and purchase scales

Tabela 2 - Escalas hedónica e compra

\begin{tabular}{c|ll}
\multicolumn{2}{l}{ Hedonic / Hedónica } & Purchase / Compra \\
\hline 5 & Very pleasant / Muito agradável & Certainly buy / Compraria de certeza \\
4 & Pleasant / Agradável & Would probably buy / Provavelmente compraria \\
3 & Indifferent / Indiferente & Don't know if I would buy / Não sei se compraria \\
2 & Unpleasant / Desagradável & Probably wouldn't buy / Provavelmente não compraria \\
1 & Very unpleasant / Muito desagradável & Certainly wouldn't buy / Não compraria de certeza
\end{tabular}

\section{Sensory evaluation}

The use of trained tasting panels is more typical for conducting descriptive testing, and the use of untrained panels may be suitable for the technique of free-choice profiling $(13,14)$. In this study, a preliminary sensory evaluation was made. A group of 53 untrained individuals, mainly researchers and students, voluntarily joined the evaluation, which included tasting of the salty crackers and a survey.

Although the frequency scale most used is the ninepoint scale by Meilgaard (13), the 5-point scale proposed by Moskowitz (14) proved to be more appropriate (15). The attributes evaluated in this evaluation were colour, aroma, flavour, texture, and overall impression, using a 5-point hedonic scale (Table 2). The intention to purchase was also parameterized according to a 5-point scale, shown in Table 2.

At the end of the survey, the participants choose that which they "best like" and the one they "least like" among all of the crackers.

\section{Statistical analysis}

Data are presented either as means and standard deviation (SD) for continuous variables or numbers and percentages for dichotomous variables. The distribution of the selected characteristics between groups was compared using $\chi 2$ tests for categorical variables or Student's t-tests or analysis of variance (ANOVA), as appropriate, for continuous variables. All statistical tests were two-tailed, and the significance level was set at $p<0.05$. All analyses were performed using the SPSS software version 26.0 (SPSS Inc, Chicago, IL). ma retangular $(2,5 \mathrm{~cm} \times 2 \mathrm{~cm})$ e repousou por $10 \mathrm{~min}$, seguindo para a cozedura no forno elétrico (Arianna), a $160{ }^{\circ} \mathrm{C}$ durante $15 \mathrm{~min}$. Por fim, procedeu-se à secagem na estufa a $60{ }^{\circ} \mathrm{C}$ (Arianna), durante $30 \mathrm{~min}$. O procedimento utilizado encontra-se descrito na Figura 1.

\section{Avaliação sensorial}

A utilização de painéis de provadores treinados é mais usual para conduzir testes do tipo descritivo e o uso de painéis não treinados, mais apropriados para a técnica de perfil de escolha-livre (13-14). Neste estudo foi realizado um estudo preliminar de avaliação sensorial com um grupo de 53 indivíduos não treinados, sobretudo investigadores e estudantes que aderiram voluntariamente à avaliação sensorial que incluiu a prova das bolachas e preenchimento de um inquérito.

Embora a escala de frequência mais utilizada seja a escala de nove pontos de Meilgaard (13) esta foi substituída pela escala de 5 pontos proposta por Moskowitz (15) que mostrou ser mais adequada (11). Os atributos avaliados nesta avaliação sensorial foram cor, aroma, sabor, textura e impressão global, recorrendo a uma escala hedónica de 5-pontos (Tabela 2). A intenção de compra foi igualmente parametrizada segundo uma escala com 5-pontos, que consta na Tabela 2 . No final do inquérito foi solicitado aos participantes que escolhessem entre todas as bolachas avaliadas a que "gostei mais" e a que "gostei menos".

\section{Análise estatística}

Os dados são apresentados como médias e desvio padrão (DP) para variáveis contínuas ou números e percentagens para variáveis dicotómicas. Comparámos a distribuição das características selecionadas entre os grupos usando testes de Pearson $\chi 2$ para variáveis categóricas ou testes $t$ de Student ou análise de variância (ANOVA), conforme apropriado, para variáveis contínuas. Todos os testes estatísticos foram bicaudais e o nível de significância foi estabelecido em $p<0,05$. To- 
das as análises foram realizadas utilizando o software SPSS versão 26.0 (SPSS Inc, Chicago, IL).

\section{Results and Discussion}

The participants in the present analyses included 53 individuals, of which $71.70 \%$ were females from 19 to 83 years old, and $28.30 \%$ were males from 14 to 72 years old. Mean age according to gender is shown in Table 3. Grape pomace crackers feature an attractive look and colour characteristic of wine products, particularly in the case of Touriga Nacional. The coloration depends on the type of grape pomace variety used, with violet tones in the case of Touriga Nacional and brown tones in the case of Arinto. These features can be observed in Figure 2.

According to the results observed in Table 4 regarding the sensorial analysis of the different types of crackers, the Arinto $10 \%$ cracker clearly had the highest score of colour, flavour, texture, global appreciation, and purchase intention, compared to the rest of the crackers with different incorporation and/or variety. However, none of these results were statistically significant, and this may be due to the small sample included.

The results regarding the sensory parameters evaluated are shown in Figure 3, and the results obtained in relation to purchasing intention are shown in Figure 4.

\section{Resultados e Discussão}

Os participantes neste estudo incluíram 53 indivíduos, sendo $71,70 \%$ do sexo feminino, de 19 a 83 anos, e $28,30 \%$ do sexo masculino, de 14 a 72 anos. A média de idade de acordo com o sexo pode ser observada na Tabela 3.

As bolachas de bagaço de uva apresentam uma aparência atraente e característica da cor dos produtos vitivinícolas que lhe deram origem, em especial a de bagaço de Touriga Nacional. A coloração depende da casta de bagaço de uva utilizada, com tons violetas no caso da Touriga Nacional e tons marrons no caso da Arinto. Todos esses resultados podem ser observados na Figura 2. De acordo com os resultados observados na Tabela 4 em relação à avaliação sensorial dos diferentes tipos de bolachas, fica claro que as de $10 \%$ da Arinto são as que apresentam maior pontuação de cor, sabor, textura, valorização global e intenção de compra, comparados para o resto das bolachas com incorporação e/ou variedade diferentes. No entanto, nenhum desses resultados foi estatisticamente significativo, o que pode ser devido à pequena amostra estudada.

A Figura 3 apresenta os resultados referentes aos

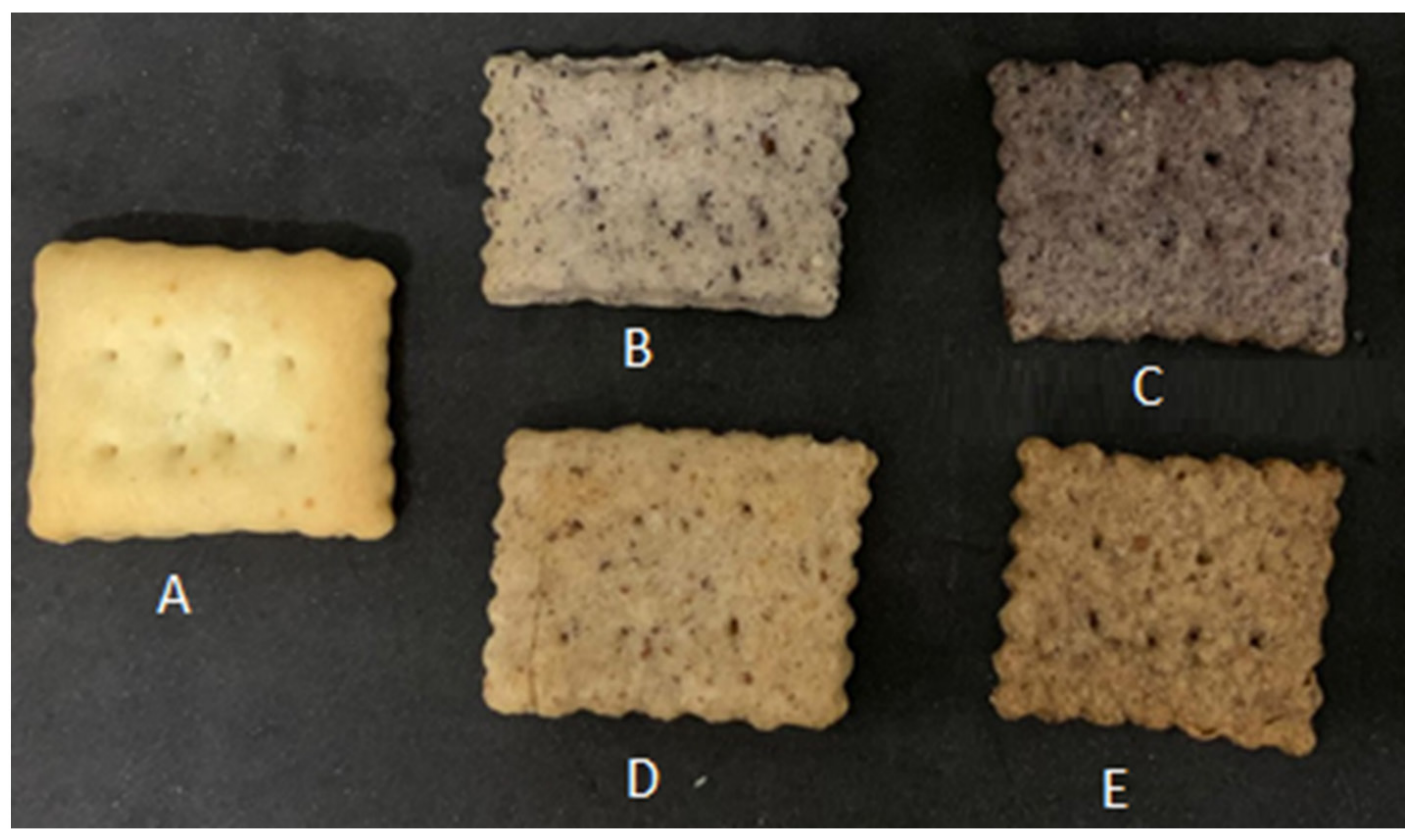

Figure 2 - Control cracker, without incorporation of grape pomace, (A); crackers with flour incorporation of the Touriga Nacional 5\% (B) and 10\% (C), crackers with flour incorporation of the Arinto 5\% (D) and 10\% (E). Figura 2 - Bolacha controlo, sem incorporação de bagaço, (A); bolachas com incorporação de farinha da casta Touriga Nacional 5\% (B) e 10\% (C), bolachas com incorporação de farinha da casta Arinto 5\% (D) e 10\% (E) 
Table 3 - Mean age according to gender. Age expressed as means (standand deviation/SD). *p values for comparisons between groups were tested by Student's t-test

Tabela 3 - Idade expressa em média (desvio padrão/DP). *Valores P para comparações entre grupos foram testados mediante teste $t$ de Student.

\begin{tabular}{lcccc}
\hline & $\begin{array}{c}\text { All population / } \\
\text { População tot. } \\
(\mathrm{n}=53)\end{array}$ & $\begin{array}{c}\text { Men / } \\
\text { Homem } \\
(\mathrm{n}=15)\end{array}$ & $\begin{array}{c}\text { Women / } \\
\text { Mulher } \\
(\mathrm{n}=38)\end{array}$ & $\begin{array}{c}\text { p-value }^{* /} \\
\text { Valores } \boldsymbol{P}^{*}\end{array}$ \\
\hline Age/ idade, & $43.96(13.08)$ & $44.07(14.76)$ & $43.92(12.57)$ & 0.971 \\
years/ anos & 46.92 & &
\end{tabular}

\section{Sensory evaluation / Avaliação sensorial}

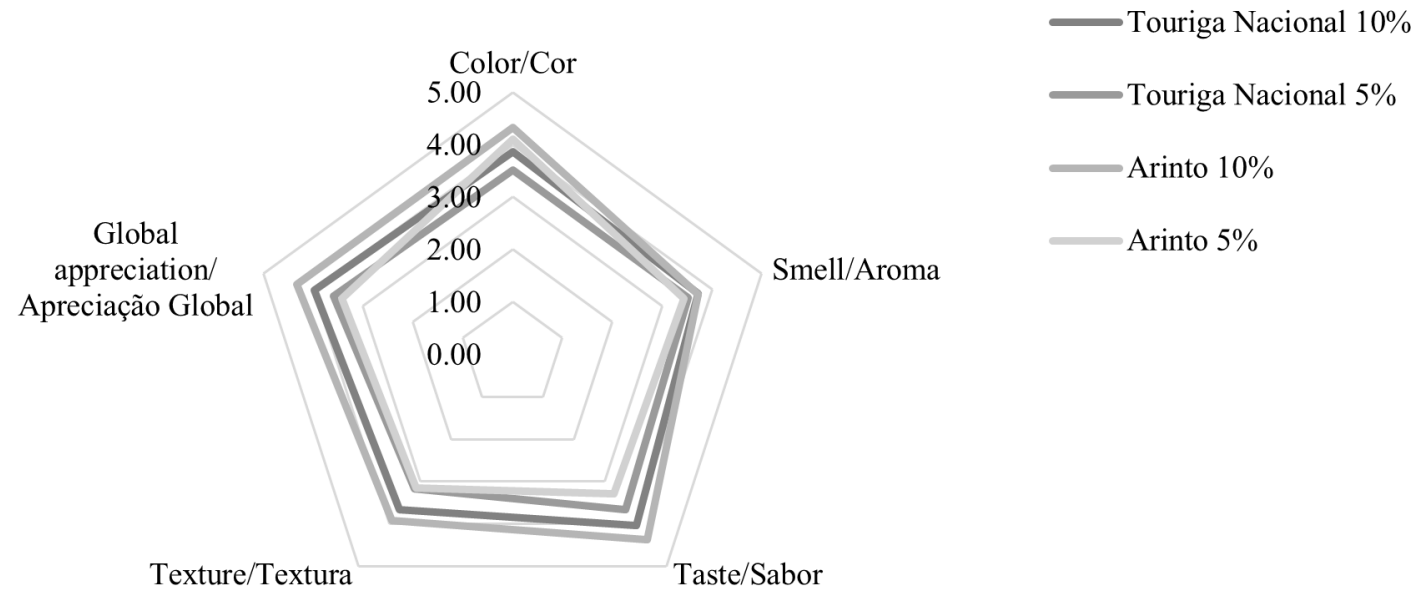

Figure 3 - Responses obtained from the participants $(\mathrm{n}=53)$ in the sensory evaluation for $5 \%$ and $10 \%$

Touriga Nacional salty crackers, and 5\% and 10\% Arinto. 1 - "very unpleasant," 2 - "unpleasant," 3 "indifferent," 4 - "pleasant," 5 - "very pleasant"

Figura 3 - Respostas obtidas do painel de participantes $(n=53)$, para bolachas salgadas de Touriga Nacional 5\% e 10\%, e Arinto 5\% e 10\%. 1 - "muito desagradável," 2 - "desagradável," 3 - "indiferente," 4 - "agradável," 5 - "muito agradável"

According to the results in Figure 3, the most appreciated crackers were $10 \%$ Arinto, with average overall values of 4.32 in colour, 3.72 in aroma, 4.32 in flavour and 3.92 in texture. The Touriga Nacional 10\% cracker was the second most appreciated, with average values of 3.87 in colour, 3.73 in aroma, 4.03 in flavour and 3.67 in texture. The lower incorporation levels were less accepted, with the Arinto 5\% having the worst attributes, with a global average value of 4.10 for colour, 3.43 for aroma, 2.29 for flavour and 3.14 for the texture. The Touriga Nacional 5\% registered 3.52 for colour, 3.52 for flavour, 3.66 for flavour, and 3.17 for texture. The "like best" and "like least" choice for the four crackers are presented in Table 5. The individuals included in the analysis reported that the cracker that they "best like" was the Touriga $10 \%$ with $39.60 \%$ of the total evaluation and the cracker that they "least like" was the Touriga $5 \%$ with $41.50 \%$. It is important parâmetros sensoriais avaliados e a Figura 4 os resultados obtidos em relação à intenção de compra. De acordo com os resultados da figura 3, as bolachas mais apreciadas foram as de $10 \%$ Arinto, com valores gerais médios de 4,32 em cores, 3,72 em aroma, 4,32 em sabor e 3,92 em textura. As de 10\% Touriga Nacional com valores médios de 3,87 em cores, 3,73 em aroma, 4,03 em sabor e 3,67 em textura foram os segundos mais apreciados. Os níveis de incorporação menor foram menos aceites, sendo o Arinto $5 \%$ a fórmula com os piores atributos, com valor médio global de 4,10 para cor, 3,43 para aroma, 2,29 para sabor e 3,14. para a textura. A Touriga Nacional 5\% registou 3,52 para cor; 3,52 para sabor, 3,66 para sabor e 3,17 para textura. A escolha da bolacha que "gostei mais" e da que "gostei menos" está apresentada na Tabela 5. Os indivíduos incluídos na análise escolheram que a bolacha "Touriga $10 \%$ " com $39,60 \%$ da avaliação total como a que 


\section{Purchase intention/Intenção de compra}

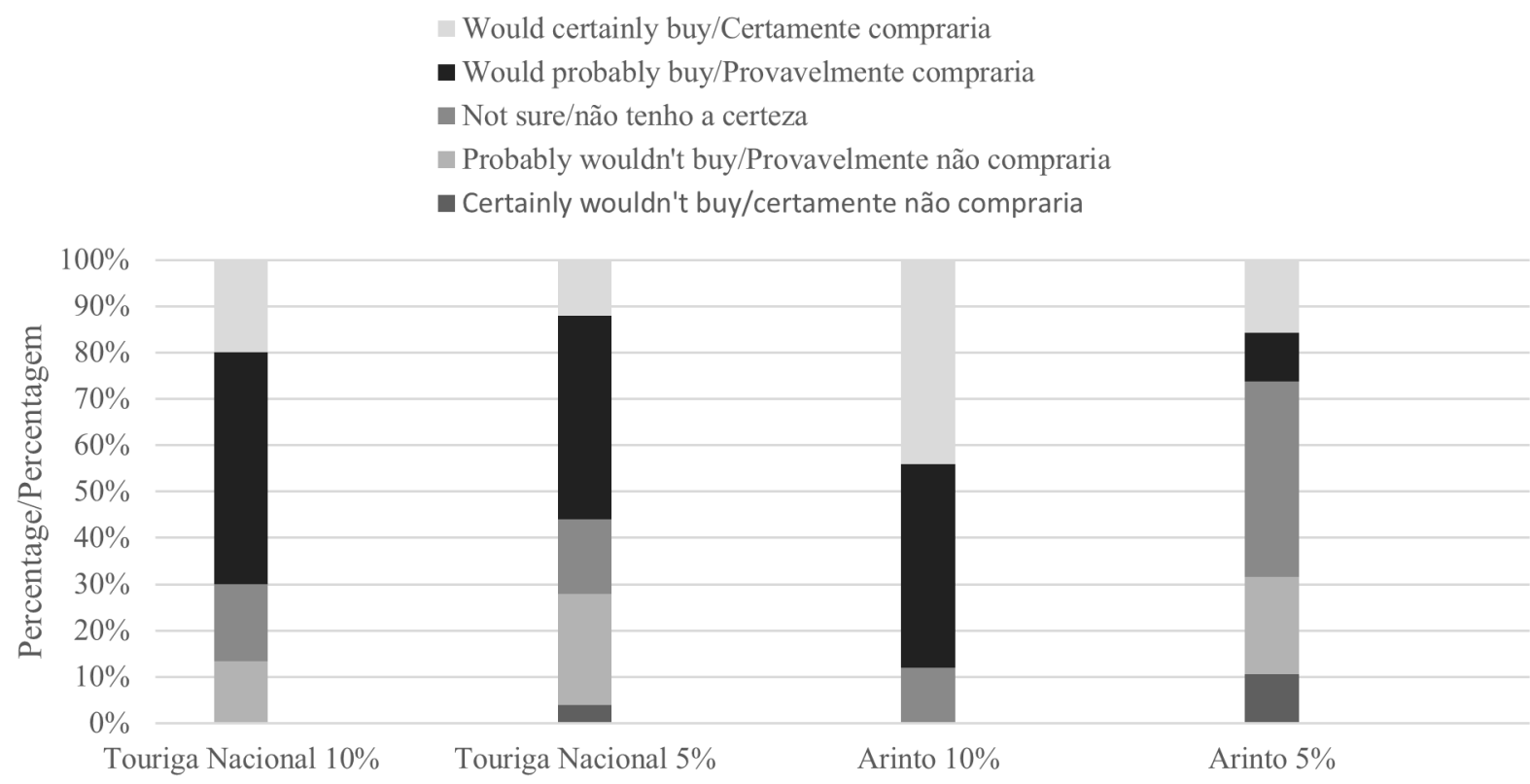

Figure 4 - Responses obtained from the tasters $(n=53)$ in the sensory evaluation in relation to purchasing intention, for 5\% and 10\% Touriga Nacional salty crackers, and 5\% and 10\% Arinto crackers

Figura 4 - Resultados obtidos na avaliação sensorial $(n=53)$ em relação à intenção de compra, para bolachas salgadas de Touriga Nacional 5\% e 10\% e Arinto 5 e $10 \%$

\begin{tabular}{|c|c|c|c|c|c|c|}
\hline & $\begin{array}{c}\text { Control / } \\
\text { Controlo } \\
(n=41) \\
\end{array}$ & $\begin{array}{c}\text { Touriga } \\
\text { Nacional 10\% } \\
(\mathrm{n}=30) \\
\end{array}$ & $\begin{array}{c}\text { Touriga } \\
\text { Nacional 5\% } \\
(n=29) \\
\end{array}$ & $\begin{array}{l}\text { Arinto } 10 \% \\
(n=25)\end{array}$ & $\begin{array}{c}\text { Arinto 5\% } \\
(n=21)\end{array}$ & $\begin{array}{l}\text { p-value } * / \\
\text { Valores } P *\end{array}$ \\
\hline Colour / Cor & $3.46(0.75)$ & $3.87(0.78)$ & $3.52(0.57)$ & $4.32(0.69)$ & $4.10(0.83)$ & 0.097 \\
\hline Flavour / Aroma & $3.17(0,70)$ & $3.73(0.83)$ & $3.52(0.63)$ & $3.72(0.84)$ & $3.43(0.60)$ & 0.153 \\
\hline Taste / Sabor & $3.15(0.79)$ & $4.03(0.81)$ & $3.66(0.72)$ & $4.36(0.64)$ & $3.29(0.72)$ & 0.168 \\
\hline Texture / Textura & $2.95(1.02)$ & $3.67(1.09)$ & $3.17(0.85)$ & $3.92(0.95)$ & $3.14(1.20)$ & 0.172 \\
\hline $\begin{array}{l}\text { Global appreciation / } \\
\text { Apreciação global }\end{array}$ & $3.07(0.85)$ & $3.97(0.89)$ & $3.59(0.73)$ & $4.32(0.56)$ & $3.43(0.75)$ & 0.089 \\
\hline $\begin{array}{l}\text { Purchase intention / } \\
\text { Intenção de compra }\end{array}$ & $2.78(1.14)$ & $3.87(0.94)$ & $3.34(1.11)$ & $4.32(0.69)$ & $3.00(1.18)$ & 0.074 \\
\hline
\end{tabular}

Table 4 - Sensory evaluation according the diferent incorporation and varities. Data expressed as means (SD). *p-values for comparisons between groups were tested by Pearson $\chi 2$. Score: Color, Aroma, Flavor, Texture, Global impression=1-Very unpleasant, 2-Unpleasant, 3-Indifferent, 4-Pleasant, 5-Very pleasant; Purchase intention=1-Certainly wouldn't buy, 2-Probably wouldn't buy, 3-Don't know if I would buy, 4-Would probably buy, 5-Ceratainly buy.

Tabela 4 - Análise sensorial de acordo as diferentes incorporações e castas. Dados expressos em médias (SD). *Valores P para comparações entre grupos foram testados mediante Pearson $\chi 2$. Pontuação: Cor, Aroma, Sabor, Textura, Impressão global=1-Muito desagradável, 2-Desagradável, 3-Indiferente, 4-Agradavél, 5-Muito agradável; Intenção de compra=1-Não compraria de certeza, 2-Provavelmente não compraria, 3-Não sei se compraria, 4-Provavelmente compraria, 5- Compraria de certeza. 
Table 5 - Best and least liked crackers choice results. Data expressed as percentage (n). *p-values for comparisons between groups were tested by Pearson $\chi 2$

Tabela 5 - Resultados da escolha da bolacha que mais e menos gostaram. Dados expressos como percentagem (n). *Valores P para comparações entre grupos foram testados mediante Pearson $\chi^{2}$

\begin{tabular}{cccccc}
\hline & $\begin{array}{c}\text { Touriga } \\
\text { Nacional 10\% }\end{array}$ & $\begin{array}{c}\text { Touriga } \\
\text { Nacional 5\% }\end{array}$ & Arinto 10\% & Arinto 5\% & $\begin{array}{c}\text { p-value*/ } \\
\text { Valores P* }\end{array}$ \\
\hline $\begin{array}{c}\text { Best like /Gostei mais } \\
(\mathrm{n}=48)\end{array}$ & $39.60(21)$ & $9.40(5)$ & $34.0(18)$ & $7.50(4)$ & 0.864 \\
$\begin{array}{c}\text { Least like / Gostei menos } \\
(\mathrm{n}=48)\end{array}$ & $13.20(7)$ & $41.50(22)$ & $5.70(3)$ & $30.20(16)$ & 0.732
\end{tabular}

to remind that these results are different from those observed in Table 4, where Arinto $10 \%$ obtained the highest score in most of the parameters because more individuals were tasting Touriga crackers than Arinto crackers. Nevertheless, these differences can also be explained by the fact that the individual may behave differently when faced with a sensory evaluation with several attributes and with a hedonic scale of several points or when an emotional response of like or dislike is requested (16).

\section{Conclusion}

This preliminary evaluation made it possible to understand a possible trend in the national market related to different incorporations of grape pomace flour of the Touriga Nacional and Arinto varietals in salty crackers. The results show a greater preference in terms of the parameters evaluated (colour, flavour, texture, purchase intention, and global appreciation) for crackers with the incorporation of $10 \%$ flour in both varieties. Considering the appreciation of the participants, the results indicated that the use of these residues has potential for use as an ingredient in food enrichment since the most accepted and most appreciated crackers were those with the highest percentage of grape pomace flour incorporation. Therefore, it would be interesting to increase the percentage of incorporation of this ingredient in the future, with a view to promoting an increase in the nutritional value of products for human consumption. Similar studies involving the incorporation of this type of flour from different grape varietals and food matrices also showed a high level of high acceptance $(17,18)$, although Acun and Gül (19) have emphasized that foods with more than $10 \%$ incorporation of grape pomace flour have decreasing acceptance. Based on the description of the different matrices previously studied and this preliminary study, we consider, with a view to "gostei mais" e "Touriga 5\%" como a que "gostei menos" com 41,50\%. É importante ressaltar que esses resultados são diferentes dos observados na Tabela 4 , onde o "Arinto 10\%" obteve a pontuação mais alta na maioria dos parâmetros, não só porque houve mais pessoas provando bolachas Touriga do que bolachas Arinto, mas também porque, quando é solicitada uma resposta emocional do tipo "gosto" ou "não gosto", o indivíduo pode comportar-se de maneira diferente quando confrontado com uma avaliação sensorial com vários atributos e com uma escala hedônica de vários pontos (16).

\section{Conclusão}

A avaliação preliminar realizada permite compreender uma possível tendência do mercado nacional relacionada com diferentes incorporações de farinha de bagaço de uva das variedades Touriga Nacional e Arinto em biscoitos salgados. Os resultados mostram uma maior preferência em termos dos parâmetros avaliados (cor, sabor, textura, intenção de compra e valorização global) pelos biscoitos com incorporação de $10 \%$ de farinha em ambas as variedades. Considerando a apreciação do participante, os resultados indicaram que a utilização destes resíduos apresenta potencial para uso como ingrediente no enriquecimento de alimentos, uma vez que, os biscoitos mais aceitos e mais apreciados foram aqueles com maior percentagem de incorporação de farinha de bagaço de uva. Seria, portanto, interessante aumentar a percentagem de incorporação no futuro, com vistas a promover o aumento do valor nutricional deste potencial ingrediente para o consumo humano, uma vez que outros estudos semelhantes, realizados com a incorporação deste tipo de farinha, mas com diferentes variedades e matrizes alimentares, mostraram também um elevado nível alto nível de aceitação $(17,18)$, embora Acun e Gül (19) tenham enfatizam que 
consolidating the results obtained, the realization of a new study with incorporation greater than $10 \%$, with a significantly larger number of participants, and with groups of trained tasters.

\section{Conflict of Interest}

The authors declare that there is no financial or personal relationship that could present a potential conflict of interests.

\section{Author Contributions Statement}

MLP - study design, writing

$\mathrm{MN}$ - supervision, final revision

PP- data analysis, supervision

RG, MR, SG - implementation

NT, MCN - revision

$\mathrm{CP}$ - statistical analysis alimentos com incorporação de farinha de bagaço de uva superior a 10\% têm aceitação decrescente. Com base no descrito para diferentes matrizes já estudadas e este estudo preliminar, consideramos, com vistas à consolidação dos resultados obtidos, a realização de um novo estudo com incorporação superior a $10 \%$, com um número significativamente maior de participantes, e com grupos de provadores treinados.

\section{Conflito de Interesses}

Os autores declaram que não existe uma relação financeira ou pessoal que possa ser entendida como representando um potencial conflito de interesses.

\section{Declaração de Contribuições do Autor}

MLP - desenho do estudo, redação

MN - supervisão, revisão final

PP - análise de datos, supervisão

RG, MR, SG - implementação

NT, MCN - revisão

$\mathrm{CP}$ - análise estatística 


\section{References / Referências}

1. IVV, "IVV // Vinha,” Estatistica/Produção 2019, 2019. [Online]. Available: https://www.ivv.gov.pt/np4/35/. [Accessed: 26-Oct-2019].

2. OIV, "International Organisation of Vine and Wine," Report, 2017. [Online]. Available: http://www.oiv.int/. [Accessed: 08-Nov-2017].

3. L. M. L. R. Silva, “Caracterização dos subprodutos da vinificação,” Spectrum, vol. 28, pp. 123-133, 2003.

4. M. Nicolai, P. Pereira, P. Rijo, O. Amaral, A. Amaral, and L. Palma, "Vitis vinera L. pomace: chemical and nutritional characterization," J. Biomed. Biopharm. Res., vol. 15, no. 2, pp. 156-166, 2018.

5. J. Garcia-Lomillo and M. L. González-SanJosé, “Applications of Wine Pomace in the Food Industry: Approaches and Functions,” Compr. Rev. Food Sci. Food Saf., vol. 16, no. 1, pp. 3-22, 2017.

6. A. B. B. Bender et al., "Obtenção e caracterização de farinha de casca de uva e sua utilização em snack extrusado,” Brazilian J. Food Technol., vol. 19, no. 0, pp. 1-9, 2016.

7. L. F. Ribeiro, R. H. Ribani, T. M. G. Francisco, A. A. Soares, R. Pontarolo, and C. W. I. Haminiuk, "Profile of bioactive compounds from grape pomace (Vitis vinifera and Vitis labrusca) by spectrophotometric, chromatographic and spectral analyses," J. Chromatogr. B, vol. 1007, pp. 72-80, Dec. 2015.

8. A. C. Jacques, F. M. Oliveira, J. V Hernandes, and E. F. Silva, "Elaboração de Farinha de uva Utilizando bagaço da indústria Vitivinícola: efeito sob os compostos fenólicos," 2014

9. R. Walker, A. Tseng, G. Cavender, A. Ross, and Y. Zhao, "Physicochemical, Nutritional, and Sensory Qualities of Wine Grape Pomace Fortified Baked Goods," J. Food Sci., vol. 79, no. 9, pp. S1811-S1822, 2014.

10. V. Kuchtová, J. Karovičová, Z. Kohajdová, L. Minarovičová, and V. Kimličková, “Effects of white grape preparation on sensory quality of cookies,” Acta Chim. Slovaca, vol. 9, no. 2, pp. 84-88, 2016.

11. D. M. Barrett, J. C. Beaulieu, and R. Shewfelt, "Color, flavor, texture, and nutritional quality of fresh-cut fruits and vegetables: Desirable levels, instrumental and sensory measurement, and the effects of processing," Crit. Rev. Food Sci. Nutr., vol. 50, no. 5, pp. 369-389, 2010.

12. A. P. Batista et al., "Microalgae as functional ingredients in savory food products: Application to wheat crackers," Foods, vol. 8, no. $12,2019$.

13. C. T. Meigaard Morten, Civille Gail, Sensory Evaluation Techniques - CRC Press Book, 5th ed. CRC Press, 2015.

14. T. A. H. Roland P. Carpenter, David H. Lyon, Guidelines for Sensory Analysis in Food Product Development and Quality Control, 2 th ed. Aspen, 2000.

15. H. R. Moskowitz, J. H. Beckley, and A. V. A. Resurreccion, Sensory and consumer research in food product design and development, 2nd ed. IFT Press Wiley-Blakwell, 2012.

16. G. V. Civille and K. N. Oftedal, "Sensory evaluation techniques - Make 'good for you' taste 'good,”” Physiol. Behav., vol. 107, no. 4, pp. 598-605, 2012.

17. G. C. Strapasson, "Caracterização e Utilização do Resíduo de Produção de Vinho no Desenvolvimento de Alimentos com Propriedade Funcional Curitiba, 2016," Universidade Federal do Paraná, 2016.

18. C. Beres et al., "Towards integral utilization of grape pomace from winemaking process: A review," Waste Management. 2017

19. S. Acun and H. Gül, "Effects of grape pomace and grape seed flours on cookie quality,” Qual. Assur. Saf. Crop. Foods, vol. 6, no. 1, pp. 81-88, Mar. 2014. 